\title{
Evaluation of mixed mode ventilation cooling energy saving potential in nZEB: A case study in Southern Italy.
}

\author{
Roberto Stasi $1^{1,}{ }^{*}$, Francesco Ruggiero ${ }^{1}$, and Umberto Berardi ${ }^{1,2}$ \\ ${ }^{1}$ Department of Civil Engineering and Architecture, Polytechnic University of Bari, DICAR - Via \\ Edoardo Orabona, 4, 70126 Bari, Italy \\ ${ }^{2}$ Department of Architectural Science, Ryerson University, 350 Victoria St., Toronto, ON M5B 2K3, \\ Canada
}

\begin{abstract}
In recent decades, reducing the energy demand of the building sector has become a major goal of global policies. Proper design of the building-plant system is hence strategic to achieve nearly zero energy building (NZEB) target. This paper reports the results of modeling the building-plant system of an NZEB in Southern Italy. The case study is a multi-family complex of eight dwellings located in Bari, in the Apulia region. The building project originates from the energy refurbishment of a former industrial shed that was demolished and rebuilt for residential use. The planned HVAC system foresees the combined use of primary ventilation with fan-coil units fed by two ground source heat pumps (GSHP) supplied by eight vertical probes. Three hybrid ventilation strategies have been compared to evaluate the potential cooling energy saving: the first one examines an earth-to-air heat exchanger (EAHX), the second one proposes night hybrid ventilation from $10 \mathrm{pm}$ to $6 \mathrm{am}$, and the last considers the adoption of free cooling in mechanical ventilation. Economic and energy comparisons among these three approaches are reported. Using EAHX, the cooling consumption saving reached about $20.7 \%$ The use of night ventilation combined with MVS can reduce the cooling energy demand for $14.4 \%$, while free cooling in MVS produces a less effective decrease in the electricity consumption for cooling of about $7.7 \%$. All three strategies generate major benefits in the middle-season.
\end{abstract}

\section{Introduction}

Reducing energy consumption and increasing energy efficiency in the building sector are key objectives that the European Community has been pursuing in the last decades. According to the new goals of the European Green Deal for the energy transition from fossil energy to renewable one, Europe aims to be climate neutral in 2050 [1].

By 2030 the first milestone to be reached is to reduce greenhouse gas emissions by at least $40 \%$ compared to 1990 levels, cover total energy demand with a share of renewable

\footnotetext{
* Corresponding author: roberto.stasi@poliba.it
} 
energy of at least $32 \%$ and improve overall energy efficiency by at least $32.5 \%$. In Europe, approximately $40 \%$ of the final energy consumption and $36 \%$ of carbon dioxide emissions depend on the construction sector. The residential sector alone represents $26.1 \%$ of final energy consumption and $16.6 \%$ of gross inland energy consumption [2]. Therefore, such significant shares highlight the reasons for the growing importance of European energy policies to act on the European building stock. In 2010, the Energy Performance of Buildings Directive (EPBD) introduced the requirement to build only nearly zero-energy buildings (NZEB) from 2021 onwards [3]. Consistently with the EPDB, an NZEB is a highperformance building aimed to reduce at minimum its energy needs mostly covered by renewable sources $[4,5]$. Its energy performance in terms of non-renewable primary energy demand, its thermal transmittance, and its plant system efficiency must be lower than the value of a baseline building of the same shape, function, and plant system, but with standard baseline properties according to regulation (U-value, g-value, plant performance ratios, etc.).

Although more and more NZEBs spread all over Europe [6,7], NZEBs cover only a small share of the total building stock. Hence, the latest European Directive 844/2018 [8] focused also on energy refurbishment of the existing building stock, the largest share of building stock in Europe. According to the EPDB recast, member states are required to identify and develop long-term national strategies to improve the efficiency of existing residential and non-residential public and private buildings. As matter of fact, a substantial share of building stock in Europe is older than 50 years, among them, a remarkable quota is hundreds of years old.

More than $60 \%$ of residential buildings were built before the 1990 s when energy building regulations were few and inadequate. In Italy, about $86 \%$ of the existing building stock was built before 1991 [9] when the first national law on energy saving came into force. Most of the building stock has considerable shortcomings in terms of energy efficiency and needs major upgrading given the European objectives of decarbonization of the residential sector. While the objective of nearly zero energy for new buildings is easily achievable, much more complex turns out to bring existing buildings up to these standards. The higher density of the consolidated urban context, the ontological energy-intensive nature of existing buildings, and the considerable heat dispersion of the envelope mean that the decreasing of energy consumption is costly.

In line with the Italian laws [10] to refurbish the existing buildings, three types of energy efficiency measures are foreseen about the type of intervention: energy retrofitting which provides the improvement and refurbishment of the overall building, demolition, and reconstruction of the building with the same shape and restricted-energy improvements related to specific parameters or requirements such as partial renovation, installation of new heating systems or replacement of heat generators.

Several studies focused on energy refurbishment of existing buildings to improve their energy performance [11-13].

Beyond these studies, few works studied the potential in energy refurbishment of recent private residential buildings despite considering their high quotas on overall building stock and their high energy demand. Even less focused on the effectiveness of demolition and reconstruction measures to improve the energy efficiency of the existing building stock. As underlined by Dubois \& Allacker [15] especially regarding buildings with no historical value, to achieve the ambitious zero energy targets by 2050, is often more effective in longterm analysis of energy refurbishment obtained from demolition and reconstruction measures than small incremental energy savings due to partials energy retrofitting actions.

Despite searching for even higher levels of energy-saving, an important issue linked to the enforceability of NZEB target both in new buildings and in refurbished ones is the growing increase in cooling energy demand in the residential sector. Due to global warming 
consequences, the upsurge in the use of mechanical air-conditioning devices, the increasing demand for higher levels of indoor comfort, the result of the hyper-insulated envelope and airtight buildings, energy use for cooling is taking an increasing share in the building energy balance [16-18]. Consequently, the implementation of natural cooling techniques in NZEB may help to restore comfort conditions inside buildings by reducing the use of mechanical cooling systems.

To reduce the energy demand of buildings especially in the Mediterranean climate, the adoption of various passive energy-saving techniques such as night ventilation, exclusively or coupled with novel thermal energy storage like phase change materials (PCMs) or other energy-efficient systems such as a free cooling system, earth-to-air heat exchanger, bioclimatic atriums, and so forth can bring a significant decrease in energy cooling consumption [19].

As stated by Ledo Gomis et al. [20], ventilative cooling technologies have the potential to be an effective measure to reduce buildings' energy consumption, by meeting some or all the cooling requirements of a building without the need for mechanical cooling.

Regarding this topic, D. D'Agostino et al. [21] estimated the employment of an EAHX as a pre-treating unit of an air conditioning system for energy saving, stated that this technology brings the best benefits in cities characterized by the greatest temperature excursion. Stasi et al. [22] probed that in an NZEB in Mediterranean climate a 32\% cooling energy reduction can be obtained using an EAHX combined with free cooling. Even though these techniques alone can't ensure the overall cooling load in NZEB, thanks to hybrid ventilation with the integral use of both natural and mechanical cooling systems, the building can achieve their thermal comfort conditions reducing cooling energy exploiting the cooling potential provided by the climate [23].

This paper reports the results of modelling the building-plant system of an NZEB in Southern Italy. The case study is a multi-family complex of eight dwellings located in Bari, in the Apulia region. The building project originates from the energy refurbishment of a former industrial shed that was demolished and rebuilt for residential use.

Three hybrid ventilation strategies have been compared to evaluate the potential cooling energy saving: the first one examines an earth-to-air heat exchanger, the second one proposes night hybrid ventilation from $10 \mathrm{pm}$ to $6 \mathrm{am}$, and the last one considers the adoption of free cooling in mechanical ventilation.

The research aims to develop benchmarks for existing building refurbishment in a Mediterranean climate, suggesting possible technological to reach cooling energy savings in NZEB buildings.

\section{Case study}

The case study provides the energy refurbishment of a former industrial shed with an overall surface of $1078 \mathrm{~m}^{2}$, demolished and rebuilt for residential use in Bari (Italy) according to NZEB targets. From a morphological and planovolumetric point of view, the new building complex was rebuilt with the same site area, maintaining the existing alignments and distances, and preserving the overall gross height and shape of the existing one.

The new residential building features eight housing units. All the units are developed on two above-ground levels and are characterized by a ground floor consisting of an openspace living area, a dining area with a kitchen, and a sleeping area accessible through a hallway connecting a double and a single bedroom and bathroom.

The first floor, on the other hand, which is accessed by an internal staircase located in the living area, contains an office room and a washroom (Fig. 1). The main building and climatic site features are highlighted in Table 1. 
Table 1. Site climatic properties and case study building features.

\begin{tabular}{lll}
\hline Climatic characteristics & & \\
\hline Latitude & $\circ$ & $\mathrm{N} 41^{\circ} 7^{\prime} 45^{\prime \prime}$ \\
Longitude & $\circ$ & $\mathrm{E} 16^{\circ} 52^{\prime} 11^{\prime \prime}$ \\
Elevation & $\mathrm{m}$ a.s.1 & 49 \\
Minimum Dry Bulb Temperature & ${ }^{\circ} \mathrm{C}$ & 0 (11 Jan.) \\
Maximum Dry Bulb Temperature & ${ }^{\circ} \mathrm{C}$ & $39(10$ Aug.) \\
Köppen climatic classification & $\mathrm{N} . \mathrm{D}$. & $\mathrm{Csa}$ \\
Climatic zone (D.P.R. 412/93) & $\mathrm{N} . \mathrm{D}$. & $\mathrm{C}$ \\
Heating Degree Days & $\left({ }^{\circ} \mathrm{C} \square \mathrm{d}\right) / \mathrm{yr}$ & 1185 \\
Max direct solar radiation & $\mathrm{W} / \mathrm{m}^{2}$ & $932(25 \mathrm{May})$ \\
\hline Building Features & & \\
\hline Net conditioned building area & $\mathrm{m}^{2}$ & 847.86 \\
Net conditioned building volume & $\mathrm{m}^{3}$ & 2289.18 \\
Surface to volume ratio & $\mathrm{m}^{-1}$ & 0,52 \\
Scattering surface & $\mathrm{m}^{2}$ & 1723.15 \\
Gross window-wall ratio & $\%$ & 16.73 \\
\hline
\end{tabular}

\subsection{Building envelope}

On the structural side, the building is built with a reinforced concrete frame structure and with concrete slabs. The building envelope is designed to achieve an elevated standard of thermal performance with high thermal insulation and relevant thermal mass. Table 2 shows envelope thermo-physic characteristics of the main building parts.

The external walls are made of perforated brick $(\lambda=0.132 \mathrm{~W} /(\mathrm{mK}))$ and $0.07 \mathrm{~m}$ of wooden fibers slab insulation $(\lambda=0.05 \mathrm{~W} /(\mathrm{mK}))$. The vaulted ceiling is made of laminated wood beams, aluminium cladding, and insulated by wooden fiber. The stratigraphy of the ground floor offers a reinforced concrete hollow slab with XPS panels $(\lambda=0.04 \mathrm{~W} /(\mathrm{mK}))$. Polyvinyl chloride (PVC) frames with double LoE glazing argon fill are used.

Table 2. Building envelope thermo-physic features.

\begin{tabular}{lcccc}
\hline & Thickness $[\mathrm{m}]$ & $\mathrm{U}-\mathrm{value}\left[\mathrm{W} /\left(\mathrm{m}^{2} \mathrm{~K}\right)\right]$ & $\phi[\mathrm{h}]$ & $\mathrm{YIE}\left[\mathrm{W} /\left(\mathrm{m}^{2} \mathrm{~K}\right)\right]$ \\
\hline External wall & 0.435 & 0.233 & 22.75 & 0.01 \\
Ceiling & 0.250 & 0.500 & 9.160 & 0.17 \\
Ground floor & 0.350 & 0.328 & 22.18 & 0.01 \\
Windows & - & 1.563 & - & - \\
\hline Note: U=thermal transmittance $; \phi=$ thermal phase shift; YIE=periodic thermal transmittance. \\
\hline
\end{tabular}

\subsection{HVAC system}

The centralized HVAC system foresees the combined use of primary ventilation with fancoil units fed by two ground source heat pumps (GSHP) in parallel. The two hydronic GSHPs are supplied by eight vertical U-tubes with a length of $76 \mathrm{~m}$, made of cross-linked high-density polyethylene (PE-Xa) with an external diameter of $0.026 \mathrm{~m}$. Each pump has nominal thermal power equal to $32.5 \mathrm{~kW}_{\mathrm{t}}$ with a coefficient of performance (COP) of 4.06 in winter mode, and an electric power input of $8 \mathrm{~kW}$. The cooling capacity in summer is $29.5 \mathrm{~kW}_{\mathrm{t}}$ with an energy efficiency ratio (EER) of 4.72 .

Proper ventilation and indoor air quality (IAQ) are guaranteed for each residential unit by a high efficiency controlled mechanical ventilation system (MVS) with heat recovery with a declared efficiency of $90 \%$ providing a flow rate of $150 \mathrm{~m}^{3} / \mathrm{h}$ and air change rate equal to $0.5 \mathrm{~h}^{-1}$, following the UNI 10339 and UNI 16798-1 [24,25]. Heating and cooling 
water coils of the air handling unit (AHU) are powered by GSHPs. Domestic hot water (DHW) production is provided by eight solar collectors for an overall surface of $9.16 \mathrm{~m}^{2}$ which covers $99.8 \%$ of total needs. One of two GSHPs offers auxiliary power when the solar collectors' energy is not enough. The electricity building needs are offset by grid connect photovoltaic monocrystalline silicon panels placed on the vaulted ceiling for an overall surface of about $300 \mathrm{~m}^{2}$ and a peak power of $44.8 \mathrm{kWp}$.

\section{Existing building}

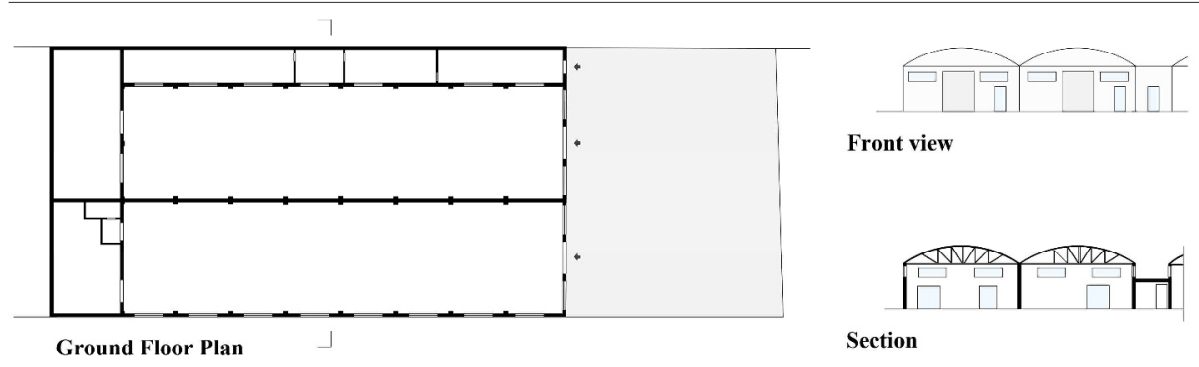

\section{Building refurbishment project}

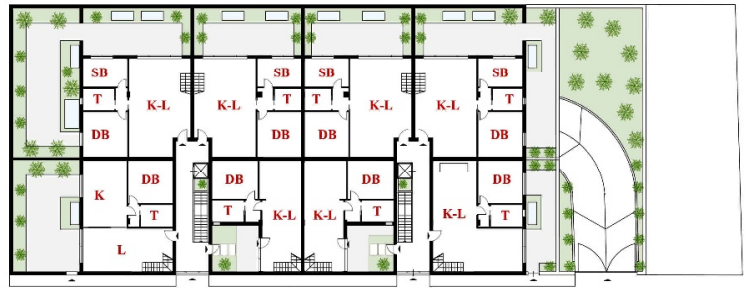

Ground Floor Plan

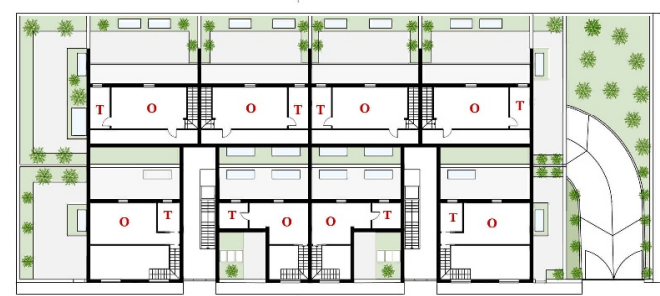

First Floor Plan

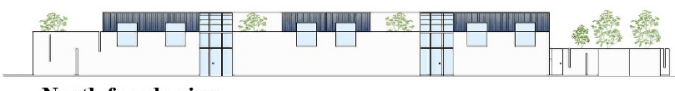

North facade view

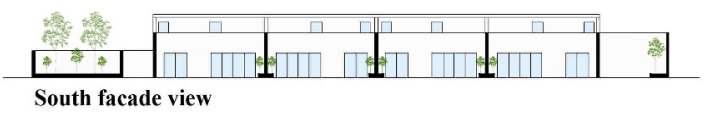

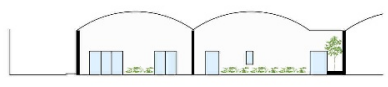

Front view

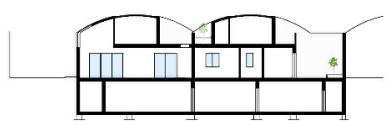

Section

Legend

$\mathrm{K}$ - Kitchen $\quad \mathrm{O}$-Office room

DR - Double hedroom SR - Single hedronm

$\mathrm{L}$ - Living room

T-Toilet

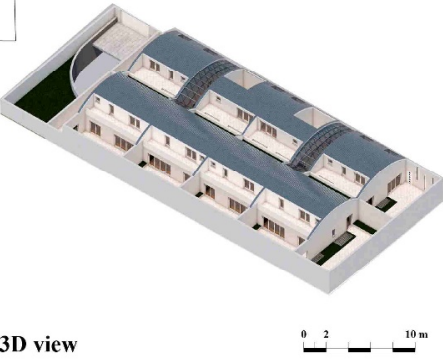

Fig. 1. Existing building vs building refurbishment project.

\section{Methodology}

Dynamic simulation of the overall building-plant system analysis on an hourly basis was performed in DesignBuilder [26], a building performance simulation software based on 
EnergyPlus simulation engine. IGDG weather data for Bari-Palese was used.

The setpoint temperature was fixed at $20{ }^{\circ} \mathrm{C}$ for the heating period and $26{ }^{\circ} \mathrm{C}$ for the cooling period according to requirements for residential buildings consistent with category II of UNI EN 16798-1. The HVAC schedule was set to be always on ( $24 \mathrm{~h}$ per day). The energy needs for heating, cooling, ventilation, hot water production, lighting, and appliance electrical needs and the PV energy generation were assessed. Scheduled daily occupancy and internal heat gain for the different thermal zones used in the simulation are summarized in Table 3.

Table 3. Scheduled daily occupancy and internal heat gain for each room.

\begin{tabular}{|c|c|c|c|c|}
\hline \multirow{2}{*}{ Thermal zone } & \multicolumn{2}{|c|}{ Occupancy daily time } & \multicolumn{2}{|c|}{$\begin{array}{l}\text { Appliances and occupancy } \\
\text { load }\left[\mathrm{W} / \mathrm{m}^{2}\right]\end{array}$} \\
\hline & $\begin{array}{l}\text { From Monday to } \\
\text { Friday }\end{array}$ & Weekend & $\begin{array}{c}\text { From Monday to } \\
\text { Friday }\end{array}$ & Weekenc \\
\hline Bedroom & from 10 p.m. to 8 a.m & from 10 p.m. to 10 a.m. & 2.67 & 3.58 \\
\hline Double bedroom & from 6 p.m. to 8 a.m. & from 10 p.m. to 9 a.m. & 2.67 & 3.58 \\
\hline Living room & $\begin{array}{l}\text { from } 8 \text { a.m. to } 10 \text { a.m } \\
\text { from } 4 \text { p.m. to } 12 \text { a.m }\end{array}$ & $\begin{array}{l}\text { from } 9 \text { a.m. to } 11 \text { a.m. } \\
\text { from } 4 \text { p.m to } 12 \text { a.m. }\end{array}$ & 9 & 9 \\
\hline $\begin{array}{l}\text { Kitchen-Dining } \\
\text { room }\end{array}$ & $\begin{array}{l}\text { from } 7 \text { a.m. to } 9 \text { a.m., } \\
\text { from } 12 \text { p.m. to } 2 \text { p.m } \\
\text { from } 8 \text { p.m. to } 10 \text { p.m }\end{array}$ & $\begin{array}{l}\text { from } 7 \text { a.m. to } 9 \text { a.m., } \\
\text { from } 12 \text { p.m to } 2 \text { p.m. } \\
\text { from } 8 \text { p.m. to } 10 \text { p.m. }\end{array}$ & 9 & 9 \\
\hline Office room & $\begin{array}{l}\text { from } 9 \text { a.m. to } 1 \text { p.m. } \\
\text { from } 3 \text { p.m. to } 7 \text { p.m. }\end{array}$ & $\begin{array}{l}\text { from } 11 \text { a.m. to } 12 \text { p.m. } \\
\text { from } 5 \text { p.m. to } 7 \text { p.m. }\end{array}$ & 2.67 & 3.83 \\
\hline
\end{tabular}

To describe the matching degree between on-site energy generation and the building load, the load match index $f_{\text {load }}$, defined as the average value over an evaluation period of how the on-site generation covers the energy load was evaluated following Equation 1.

$$
\mathrm{f}_{\text {load }}=1 / \mathrm{N} \square \Sigma_{\text {year }}(\min [1, \mathrm{~g}(\mathrm{t}) / 1(\mathrm{t})])
$$

where $l(t)$ represents the energy load, $g(t)$ the onsite electricity production, $N$ is the number of samples in the evaluation period. In case that hourly resolution data are used and the evaluation period is a complete year, the number of samples is 8760 .

Furthermore, to assess the potential saving on cooling energy consumption, four scenarios characterized by different hybrid ventilation strategies were considered. Scenario 1 reports the cooling energy need in the base case considering only MVS. Scenario 2 analyses the energy benefit got by an earth-to-air heat exchanger (EAHX). Scenario 3 proposes night hybrid ventilation (NV) from 10 p.m. to 6 a.m., while scenario 4 considers the adoption of free cooling (FC) system in MVS. Four dynamic simulations on an hourly basis in the cooling period, from 25 April to 15 October, were performed considering the same building features and indoor parameters within the use of these different strategies.

\subsection{Earth-to-air heat exchanger (EAHX)}

To simulate in DesignBuilder the action of EAHX, a system of $80 \mathrm{~m}$ of polypropylene pipes $(\lambda=0.30 \mathrm{~W} /(\mathrm{mK}))$ with a diameter of $200 \mathrm{~mm}$ connected to an outside air suction tower was placed $3.50 \mathrm{~m}$ under the ground level. Moreover, intake fans were provided to improve EAHX efficiency. The soil parameters for the simulation of EAHX were obtained by EnergyPlus utility CalcSoilSurfTemp, which calculates the annual average soil surface temperature, the amplitude of soil surface temperature and the phase constant of soil surface temperature. Values achieved are shown in Table 4. An operative on/off control strategy carried out by a Building Automation System (BAS) was supplied in the 
simulation.

Table 4. Soil parameters for Bari.

\begin{tabular}{lc}
\hline Site & Bari \\
\hline Type of soil & Covered and dry \\
Average soil surface temperature & $18.3^{\circ} \mathrm{C}$ \\
Amplitude of soil surface temperature & $9.13^{\circ} \mathrm{C}$ \\
Phase constant of soil surface temperature & $59{ }^{\circ} \mathrm{C}$ \\
\hline
\end{tabular}

To avoid indoor overheating or overcooling, EAHX operating mode is granted under control rules: BAS provides to shut EAHX off when the indoor temperature $T_{\text {ind }}$ is higher than $26^{\circ} \mathrm{C}$ when heating and lower than $20^{\circ} \mathrm{C}$ when cooling. A difference between indoor and outdoor temperature $\Delta T$ equal to $3^{\circ} \mathrm{C}$ is required to let the EAHX to operate.

\subsection{Night-time hybrid ventilation (NV)}

Settings to simulate night-time ventilation include the scheduled period of openings and outdoor temperature limits. The type of window implemented is a tilt-turn window, with an automated bottom-hinged opening corresponding to $30 \%$ of the overall opening area. The scheduled operating period was set from 10 p.m. to 6 a.m.

Ventilative cooling is granted under temperature control rules: BAS allows windows to be opened when the indoor temperature $T_{\text {ind }}$ is higher than $20^{\circ} \mathrm{C}$ and outdoor temperature ranges between $20^{\circ} \mathrm{C}$ and $26^{\circ} \mathrm{C}$.

\subsection{Free cooling (FC)}

Free cooling is an operating mode supplied in MVS, which allows outside airflow directly from the outdoor to the distribution circuit, bypassing the coils of the air handling unit without energy expenditure. This mode was provided for MVS in the simulation. Moreover, an economizer operation was set. This control mode sets the outdoor airflow rate at a minimum if the outdoor air temperature is higher than a specified dry-bulb temperature limit equal to $26^{\circ} \mathrm{C}$ and lower than $20^{\circ} \mathrm{C}$.

\section{Results}

\subsection{Base case annual energy analysis}

The first analysis carried out through the dynamic simulation was to compare the thermal indoor comfort against the Italian standards and to link them to the energy consumption of the building. From the annual simulation on an hourly basis, conducted on the entire building-plant system, it was possible to evaluate the energy required to achieve living comfort conditions in both summer and winter periods. Considering the operative temperature as a reference index, plant system operations and efficiency were evaluated. As shown in Fig. 2, the building-plant system ensures the setpoint temperature suitable for indoor thermal comfort consistent with UNI 10339.

A constant operative temperature of $20{ }^{\circ} \mathrm{C}$ is achieved in winter, while during the summer period, the operative temperature does not exceed $26^{\circ} \mathrm{C}$. Energy needs for heating are required from half of October until the end of April. It peaks at roughly the same time as the minimum dry bulb external temperatures. Cooling electricity consumption, instead, is limited between 25 April and 15 October, with peaks in July and August, when the dry bulb outside temperature reaches its maximum up to $40^{\circ} \mathrm{C}$. The overall heating load required is 
equal to $16269.4 \mathrm{kWht}$ of which $61 \%\left(9927.15 \mathrm{kWh}_{\mathrm{t}}\right)$ is supplied by heat recovery, while the cooling load is $39820.89 \mathrm{kWh}_{\mathrm{t}}$.

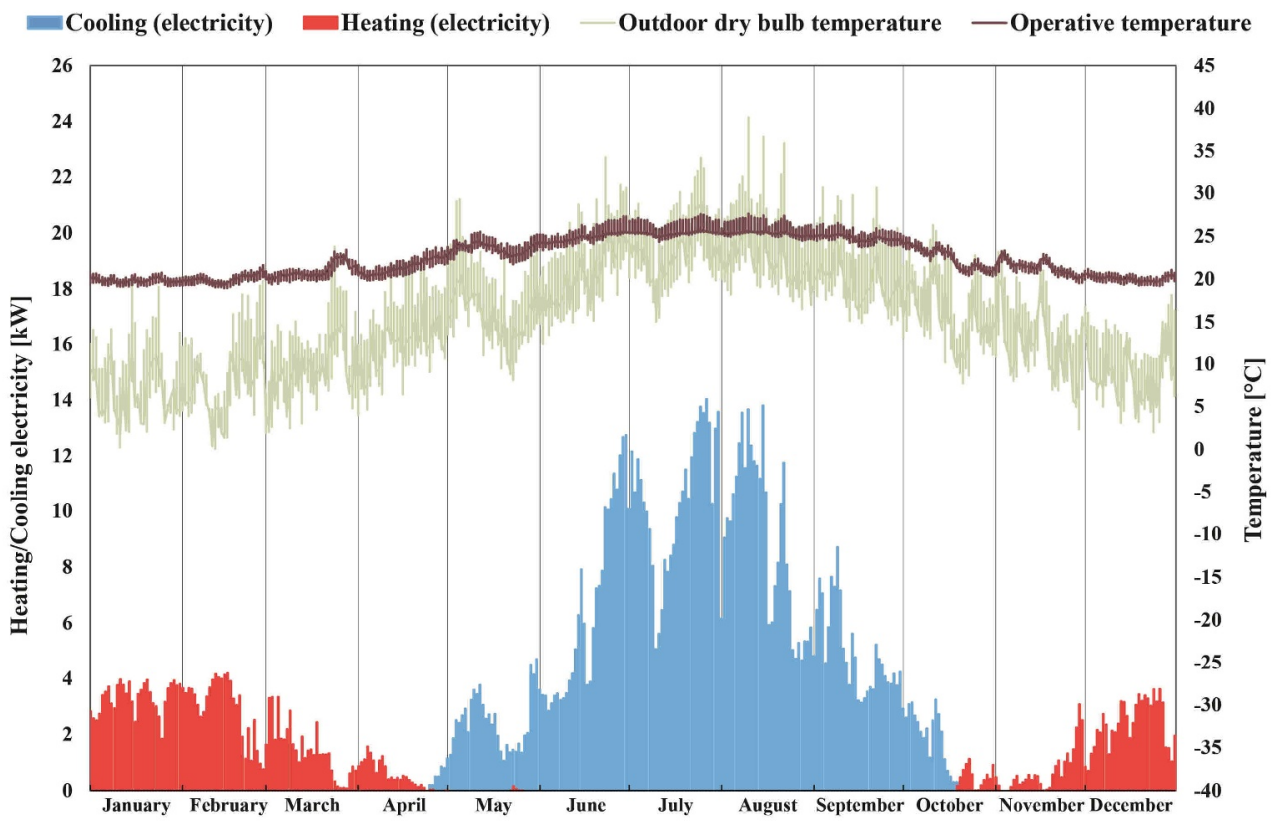

Fig. 2. Annual building-plant system analysis on hourly basis.

The main and unique energy supplier is electricity. The total annual end use electricity required by the residential complex, sum of heating $(\mathrm{H})$, cooling $(\mathrm{C})$, ventilation $(\mathrm{V})$ and domestic hot water (DHW) according to D.M. 26/06/2015 [10] is $21.6 \mathrm{kWh} / \mathrm{m}^{2} \mathrm{a}$. Heating consumption, with a share of $4.03 \mathrm{kWh} / \mathrm{m}^{2} \mathrm{a}$, accounts for $18.7 \%$ on total energy consumption, cooling $\left(12.61 \mathrm{kWh} / \mathrm{m}^{2} \mathrm{a}\right)$ for $58.4 \%$, mechanical ventilation $\left(4.85 \mathrm{kWh} / \mathrm{m}^{2} \mathrm{a}\right)$ for $22.5 \%$, DHW $\left(0.08 \mathrm{kWh} / \mathrm{m}^{2} \mathrm{a}\right)$ for $0.4 \%$. The PV system produces $52.24 \mathrm{kWh} / \mathrm{m}^{2} \mathrm{a}$ in total energy, including $9.66 \mathrm{kWh} / \mathrm{m}^{2}$ a directly consumed by the building and 42.58 $\mathrm{kWh} / \mathrm{m}^{2} \mathrm{a}$ exported to the grid. Even if the total energy generated on-site is higher than building energy needs, monthly production does not match consumption. Annual load match index $f_{\text {load }}$ on an hourly basis is equal to $51.44 \%$ and ranges from $34.5 \%$ reached in January and $56.9 \%$ in June.

\subsection{Hybrid ventilation strategies}

Monthly cooling electricity demand required by each scenario is shown in Fig. 3. Regarding total cooling energy need, base case requires $10692.3 \mathrm{kWh}$, EAHX 8478.4 KWh, NV 9152.1 kWh and FC 9866.5 kWh.

Table 5 reports the comparative analysis between scenarios for total cooling load, cooling electricity consumption, and electricity peak power on monthly basis. The maximum decrease for EAHX occurs in May and it is equal to $26.6 \%$, for NV in September with a value of $16.5 \%$, for FC in April and October with respectively $17.8 \%$ and $17.4 \%$.On total cooling electricity consumption, EAHX generates a global decrease of $20.7 \%$, reaching its maximum value in May (32.1\%) and a minimum in July (15.4\%). NV produces an energy saving on base case's consumption equal to $14.4 \%$, with the highest value achieved in September (21.8\%) and the lowest one in April (1.9\%). Moreover, FC offers a 
total reduction on cooling electricity need for $6.6 \%$ ranging from a maximum of $21.1 \%$ in October and a minimum of $2.7 \%$ during July

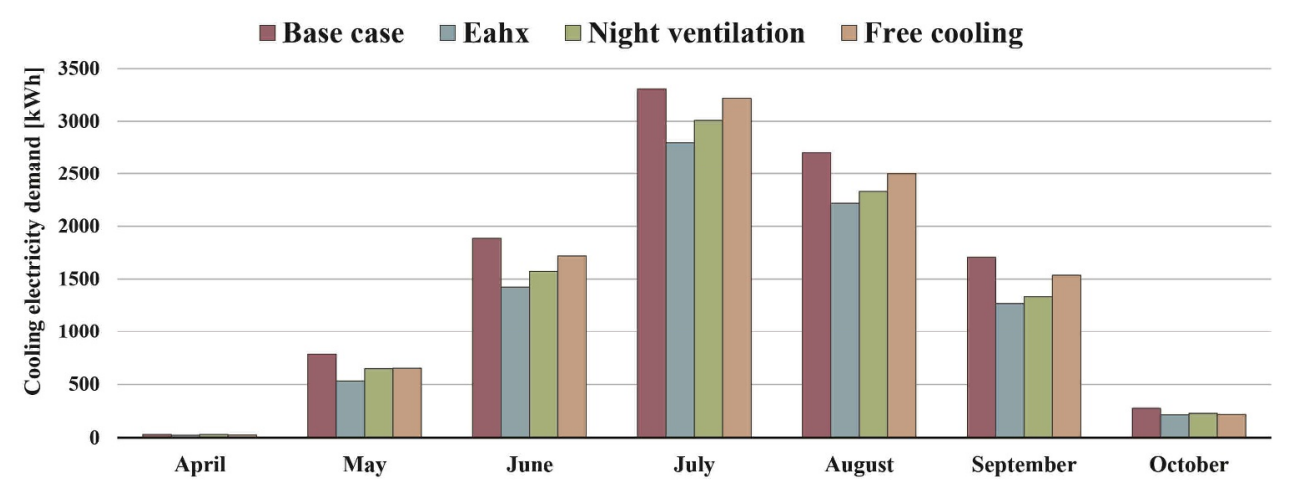

Fig. 3. Monthly cooling electricity demand required by each scenario.

Concerning the electricity peak power for cooling, the three approaches produce respectively an average decrease of $25.9 \%$ (EAHX), $8.9 \%(\mathrm{NV})$, and $3.0 \%$ (FC); while a reduction on maximum value achieved by the base case in July, equal to $6.3 \%$ (EAHX), $1.0 \%(\mathrm{NV})$ and $0.5 \%(\mathrm{FC})$.

Table 5. Comparative analysis between scenarios for total cooling load, cooling electricity consumption and electricity peak power on monthly basis.

\begin{tabular}{|c|c|c|c|c|c|c|c|c|}
\hline & April & May & June & July & August & September & October & \\
\hline & \multicolumn{7}{|c|}{ Total cooling load } & Total \\
\hline Base case & 193.6 & 4240.2 & 7663.7 & 10957.3 & 9040.3 & 6537.3 & 1188.3 & $39820.9 \mathrm{kWh}_{\mathrm{t}}$ \\
\hline Eahx & 152.0 & 3137.8 & 6221.9 & 9867.7 & 7916.8 & 5288.8 & 990.1 & $33575.5 \mathrm{kWh}_{\mathrm{t}}$ \\
\hline$\Delta \%$ & $-21.5 \%$ & $-26.0 \%$ & $-18.8 \%$ & $-9.9 \%$ & $-12.4 \%$ & $-19.1 \%$ & $-16.7 \%$ & $-15.7 \%$ \\
\hline Night ventilation & 190.4 & 3641.3 & 6636.9 & 10260.9 & 8082.9 & 5458.1 & 1037.7 & $35308.4 \mathrm{kWh}_{\mathrm{t}}$ \\
\hline$\Delta \%$ & $-1.6 \%$ & $-14.1 \%$ & $-13.4 \%$ & $-6.4 \%$ & $-10.6 \%$ & $-16.5 \%$ & $-12.7 \%$ & $-11.3 \%$ \\
\hline Free cooling & 159.1 & 3669.5 & 7123.9 & 10770.9 & 8521.2 & 6058.7 & 981.3 & $37284.8 \mathrm{kWh}_{\mathrm{t}}$ \\
\hline \multirow[t]{2}{*}{$\Delta \%$} & $-17.8 \%$ & $-13.5 \%$ & $-7.0 \%$ & $-1.7 \%$ & $-5.7 \%$ & $-7.3 \%$ & $-17.4 \%$ & $-6.4 \%$ \\
\hline & \multicolumn{7}{|c|}{ Cooling electricity consumption } & Total \\
\hline Base case & 30.5 & 782.8 & 1885.2 & 3308.4 & 2703.2 & 1705.8 & 276.1 & $10692.3 \mathrm{kWh}$ \\
\hline Eahx & 22.6 & 531.3 & 1424.4 & 2799.0 & 2216.9 & 1269.7 & 214.3 & $8478.4 \mathrm{kWh}$ \\
\hline$\Delta \%$ & $-25.9 \%$ & $-32.1 \%$ & $-24.4 \%$ & $-15.4 \%$ & $-18.0 \%$ & $-25.6 \%$ & $-22.4 \%$ & $-20.7 \%$ \\
\hline Night ventilation & 29.9 & 647.8 & 1572.5 & 3009.1 & 2330.1 & 1333.9 & 228.6 & $9152.1 \mathrm{kWh}$ \\
\hline$\Delta \%$ & $-1.9 \%$ & $-17.2 \%$ & $-16.6 \%$ & $-9.0 \%$ & $-13.8 \%$ & $-21.8 \%$ & $-17.2 \%$ & $-14.4 \%$ \\
\hline Free cooling & 24.5 & 652.7 & 1719.4 & 3218.8 & 2496.8 & 1536.3 & 217.9 & $9866.5 \mathrm{kWh}$ \\
\hline \multirow[t]{2}{*}{$\Delta \%$} & $-19.7 \%$ & $-16.6 \%$ & $-8.8 \%$ & $-2.7 \%$ & $-7.6 \%$ & $-9.9 \%$ & $-21.1 \%$ & $-7.7 \%$ \\
\hline & \multicolumn{7}{|c|}{ Electricity peak power } & Max \\
\hline Base case & 1.13 & 4.77 & 12.85 & 14.14 & 13.94 & 8.93 & 3.25 & $14.14 \mathrm{~kW}$ \\
\hline Eahx & 0.58 & 3.20 & 11.25 & 13.25 & 12.87 & 7.08 & 1.55 & $13.25 \mathrm{~kW}$ \\
\hline$\Delta \%$ & $-48.6 \%$ & $-33.0 \%$ & $-12.4 \%$ & $-6.3 \%$ & $-7.6 \%$ & $-20.7 \%$ & $-52.4 \%$ & $-6.3 \%$ \\
\hline Night ventilation & 1.10 & 4.08 & 12.38 & 14.00 & 13.56 & 7.76 & 2.46 & $14.00 \mathrm{~kW}$ \\
\hline$\Delta \%$ & $-2.5 \%$ & $-14.6 \%$ & $-3.6 \%$ & $-1.0 \%$ & $-2.7 \%$ & $-13.0 \%$ & $-24.4 \%$ & $-1.0 \%$ \\
\hline Free cooling & 1.12 & 4.84 & 12.72 & 14.07 & 13.79 & 8.75 & 2.67 & $14.07 \mathrm{~kW}$ \\
\hline$\Delta \%$ & $-0.2 \%$ & $1.4 \%$ & $-1.0 \%$ & $-0.5 \%$ & $-1.1 \%$ & $-1.9 \%$ & $-18.0 \%$ & $-0.5 \%$ \\
\hline
\end{tabular}

Note: $\Delta \%$ percentage decrease compared to base case.

Table 6 shows the percentage of cooling electricity reduction by scenario and by month. As can be seen, all the three hybrid ventilation strategies reach their greatest values during the middle seasons period (April, May, June, September, and October), during the hottest periods (July and August) lower benefits are achieved, and greater use of active cooling is 
required. EAHX produces the highest reductions in all months with an average value of $23.4 \%$. The second more effective strategy is NV which achieves an average monthly reduction of $13.9 \%$. Fewer decreases occur with $\mathrm{FC}$ which generates an average reduction equal to $12.4 \%$. Compared to NV, FC brings fewer benefits in all months except for April and October.

Table 6. Cooling electricity reduction by scenario and by month.

\begin{tabular}{|c|c|c|c|c|c|c|c|}
\hline \multicolumn{8}{|c|}{ Cooling electricity reduction by scenario } \\
\hline & Apr. & May & Jun. & Jul. & Aug. & Sept. & Oct. \\
\hline Eahx & $-25.9 \%$ & $-32.1 \%$ & $-24.4 \%$ & $-15.4 \%$ & $-18.0 \%$ & $-25.6 \%$ & $-22.4 \%$ \\
\hline Night ventilation & $-1.9 \%$ & $-17.2 \%$ & $-16.6 \%$ & $-9.0 \%$ & $-13.8 \%$ & $-21.8 \%$ & $-17.2 \%$ \\
\hline Free cooling & $-19.7 \%$ & $-16.6 \%$ & $-8.8 \%$ & $-2.7 \%$ & $-7.6 \%$ & $-9.9 \%$ & $-21.1 \%$ \\
\hline \multicolumn{8}{|c|}{ Cooling electricity reduction by month } \\
\hline & Apr. & May & Jun. & Jul. & Aug. & Sept. & Oct. \\
\hline Eahx & $-25.9 \%$ & $-32.1 \%$ & $-24.4 \%$ & $-15.4 \%$ & $-18.0 \%$ & $-25.6 \%$ & $-22.4 \%$ \\
\hline Night ventilation & $-1.9 \%$ & $-17.2 \%$ & $-16.6 \%$ & $-9.0 \%$ & $-13.8 \%$ & $-21.8 \%$ & $-17.2 \%$ \\
\hline Free cooling & $-19.7 \%$ & $-16.6 \%$ & $-8.8 \%$ & $-2.7 \%$ & $-7.6 \%$ & $-9.9 \%$ & $-21.1 \%$ \\
\hline
\end{tabular}

Fig. 4 and Fig. 5 report respectively the comparison of cooling electricity need among scenarios on hourly basis in a middle season week (from 9 to 15 May) and in the hottest summer week (from 5 to 12 August). As can be seen, in the middle season, compared to electricity consumption of the base case, EAHX produces a constant decrease in energy cooling demand and strongly reduces the electricity peak power. NV generates greater decreases in the early morning and in the evening, while it brings lower benefits than EAHX during the hottest hours. FC reaches the best benefits during the night-time when the outdoor temperature is lower, while during the day the energy demand is comparable to base case one, also in terms of peak electricity power. In the hottest summer week, when the outdoor temperature reaches its maximum and does not fall below $22^{\circ} \mathrm{C}$ at night, the action of all strategies is clearly reduced and falls most during the night. Except the EAHX, the other strategies perform comparable to the behaviour of the baseline scenario during the daytime.

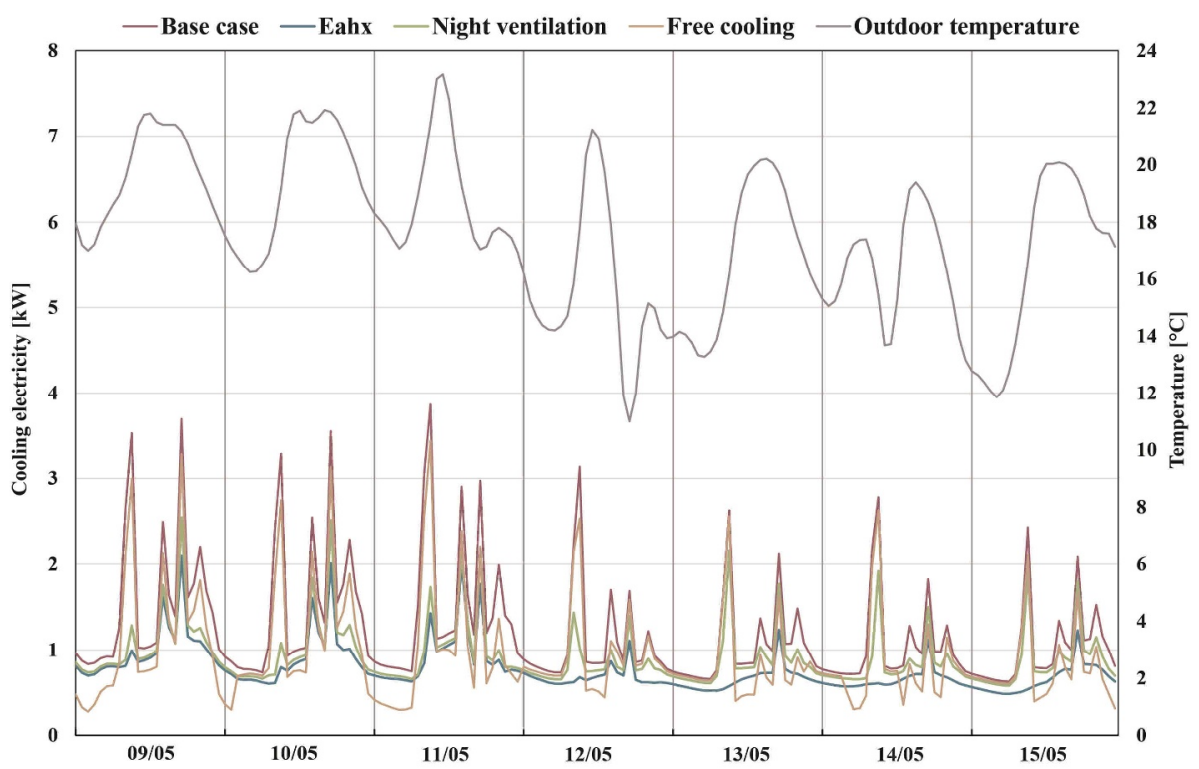

Fig. 4. Middle season week (9-15 May): cooling electricity need comparison among scenarios. 


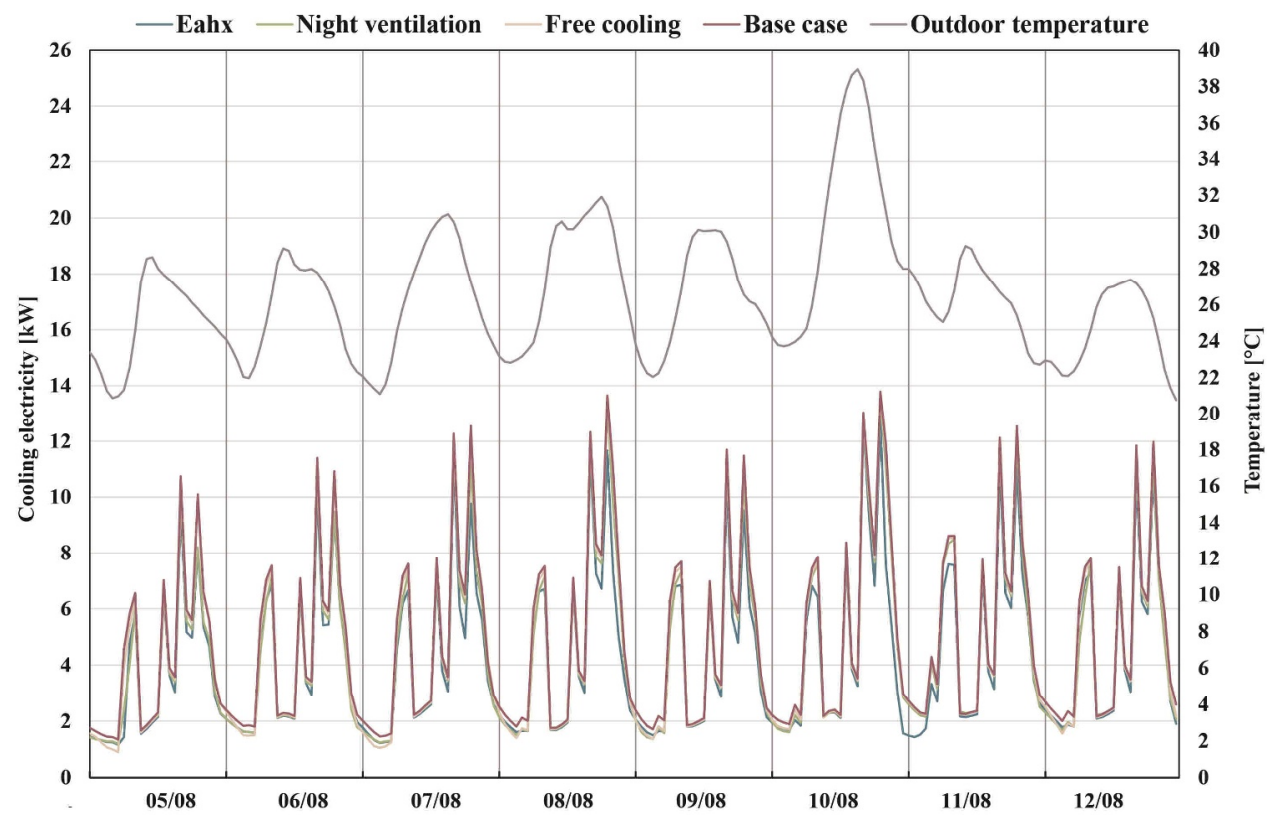

Fig. 5. Summer week (5-12 August): cooling electricity need comparison among scenarios.

Although EAHX achieves lower benefits than in the middle season period, it manages to ensure a significant decrease in electricity peak power during the hottest hours even in the summer period.

Cooling electricity-saving achieved by the three approaches produces a surplus in electricity exported $\left(W_{\text {exp }}\right)$ to the grid. Respectively EAHX produces an increase of $W_{\text {exp }}$ equal to $13.0 \%$, NV $9.1 \%$, and FC $4.9 \%$ (Table 7).

Table 7. PV generation exported electricity (Wexp), and electricity consumption.

\begin{tabular}{|c|c|c|c|c|c|c|c|c|c|c|}
\hline & & Apr. & May & Jun. & Jul. & Aug. & Sept. & Oct. & \multicolumn{2}{|c|}{ Total } \\
\hline \multicolumn{2}{|c|}{ PV on-site generation } & 363.8 & 5842.8 & 6386.5 & 6598.2 & 5633.9 & 3912.3 & 791.9 & 29529.5 & $\mathrm{kWh}$ \\
\hline \multicolumn{11}{|c|}{ Total electricity consumption } \\
\hline \multirow{2}{*}{ Base case } & Tot. $\mathrm{Co}$ & 53.1 & 1133.0 & 2223.7 & 3658.2 & 3053.0 & 2044.3 & 377.6 & 12542.7 & $\mathrm{kWh}$ \\
\hline & Wexp & 310.7 & 4709.8 & 4162 & 2940 & 2580.9 & 1868.1 & 414.3 & 16986.8 & $\mathrm{kWh}$ \\
\hline \multirow{3}{*}{ Eahx } & Tot. Consump. & 46.3 & & & & & & 315.8 & 10338.7 & $\overline{\mathrm{kWh}}$ \\
\hline & Wexp & 317.5 & 4952.5 & 4623.7 & 344 & 3067.3 & 2304.1 & 476.1 & 19190.8 & $\mathrm{kWh}$ \\
\hline & ¿\% Base case & $2.2 \%$ & $5.2 \%$ & $11.1 \%$ & $17.3 \%$ & $18.8 \%$ & $23.3 \%$ & $14.9 \%$ & $13.0 \%$ & \\
\hline \multirow{3}{*}{$\begin{array}{l}\text { Night } \\
\text { ventilation }\end{array}$} & & 52.5 & & 1910.9 & 3358 & 2679.8 & & 330.1 & 11003.2 & $\mathrm{kWh}$ \\
\hline & $W \exp$ & 311.3 & 4844.1 & 4475.6 & 3239.4 & 2954.1 & 2240.0 & 461.8 & 18526.3 & $\mathrm{kWh}$ \\
\hline & ¿\% Base case & $0.2 \%$ & $2.9 \%$ & $7.5 \%$ & $10.2 \%$ & $14.5 \%$ & $19.9 \%$ & $11.5 \%$ & $9.1 \%$ & \\
\hline \multirow{3}{*}{$\begin{array}{l}\text { Free } \\
\text { cooling }\end{array}$} & Tot. $C o$ & 47.1 & 1003.0 & 2057.8 & 3568.5 & 2846.6 & 1874.7 & 319.3 & 11716.9 & $\overline{\mathrm{kWh}}$ \\
\hline & $W \exp$ & 316.7 & 4839.9 & 4328.7 & 3029.7 & 2787.3 & 2037.6 & 472.6 & 17812.6 & $\mathrm{kWh}$ \\
\hline & $\triangle \%$ Base case & $1.9 \%$ & $2.8 \%$ & $4.0 \%$ & $3.0 \%$ & $8.0 \%$ & $9.1 \%$ & $14.1 \%$ & $4.9 \%$ & \\
\hline
\end{tabular}

To assess the cost-effectiveness of the different strategies, the payback time $\left(T_{R}\right)$ was assessed by comparing the initial investment cost (Ic) to total electricity saving compared to the base case. The investment cost has been reduced by $65 \%$ thanks to the incentives provided by Italian law for energy efficiency measures for the existing building. Total electricity saving was evaluated as the sum of the electricity-saving (ES) and revenue from the sale of surplus electricity exported (SEE) due to reduced consumptions. Average unit 
electricity cost in Italy according to Eurostat (2020) equal to $0.234 € / \mathrm{kWh}$ was used for ES to define economic savings achieved, $60 \%$ of it was used to assess the price of exported electricity to the grid in SEE. The results are shown in Table $8 . \mathrm{T}_{\mathrm{R}}$ is equal to 6.5 years for EAHX, 7.3 for NV, and 8.9 for FC.

Table 8. Evaluation of payback time (TR) achieved by each strategy.

\begin{tabular}{|c|c|c|c|c|c|c|c|c|}
\hline & \multirow{3}{*}{$\begin{array}{c}\begin{array}{c}\text { Investment } \\
\text { cost }\end{array} \\
\text { Ic } \\
\end{array}$} & \multirow{3}{*}{$\begin{array}{c}\begin{array}{c}\text { Investment } \\
\text { cost (-subsidy } \\
\mathbf{6 5 \%} \%\end{array} \\
\mathrm{I}^{*} \mathrm{c} \\
€\end{array}$} & \multicolumn{2}{|c|}{ Electricity Saving } & \multicolumn{2}{|c|}{$\begin{array}{c}\text { Surplus } \\
\text { Electricity } \\
\text { Exported }\end{array}$} & \multirow{2}{*}{$\begin{array}{c}\begin{array}{c}\text { Total } \\
\text { economic } \\
\text { saving }\end{array} \\
\text { ES+SEE } \\
\end{array}$} & \multirow{3}{*}{$\begin{array}{c}\begin{array}{c}\text { Payback } \\
\text { time }\end{array} \\
T_{R} \\
\text { vear }\end{array}$} \\
\hline & & & ES & & $\mathrm{SI}$ & $\mathrm{EE}$ & & \\
\hline & & & $\mathrm{kWh} / \mathrm{a}$ & $€ / \mathrm{a}$ & $\mathrm{kWh} / \mathrm{a}$ & $€ / \mathrm{a}$ & $€ / \mathrm{a}$ & \\
\hline & 15400 & 5390 & 2213.85 & $518.3 €$ & 2204 & $309.6 €$ & $827.8 €$ & 6.5 \\
\hline $\begin{array}{l}\text { Night } \\
\text { ventilation }\end{array}$ & 12000 & 4200 & 1540.23 & $360.6 €$ & 1539.5 & $216.2 €$ & $576.8 €$ & 7.3 \\
\hline Free cooling & 7840 & 2744 & 825.78 & $193.3 €$ & 825.8 & $116.0 €$ & $309.3 €$ & 8.9 \\
\hline
\end{tabular}

\section{Conclusions}

The study presented in this paper demonstrates that reaching NZEB targets for existing buildings is still one of the greatest challenges for the current design. Demolition and reconstruction can offer a more effective way to achieve a high level of energy performance than small energy savings due to partials energy retrofitting actions.

Furthermore, dynamic models on an hourly basis used to analyse building-plant systems are essential to estimate the complexity of the thermophysical variables to which a building is subjected and to evaluate the energy consumption and the on-site generation of a building more realistically. Despite the low overall consumption achieved by the case study, cooling energy needs account for $58.4 \%$ of total electricity consumption (sum of $\mathrm{H}, \mathrm{C}, \mathrm{V}$, and DHW). The comparison among different hybrid ventilation strategies demonstrates how appreciable cooling energy savings can be achieved even in a high-efficiency NZEB in Mediterranean climate. Using EAHX the cooling consumption saving reached is about $20.7 \%$ The use of night ventilation combined with MVS can reduce the cooling energy demand by $14.4 \%$, while free cooling in MVS produces a less effective decrease in the electricity consumption for cooling of about $7.7 \%$.

All three strategies generate the major benefits in the middle-season period when it records a greater daily thermal excursion. EAHX represents the most cost-effective strategy providing a payback period equal to 6.5 years and the most amount of energy saving.

This research was conducted within the frame of the research agreement "Nuove forme dell'abitare" between AGF-Energy company and Department of Civil Engineering and Architecture, Polytechnic University of Bari.

\section{References}

[1] European Commission, COM/2019/640 final - The European Green Deal., (2019).

[2] the S.O. of the E.U. Eurostat, Eurostat Statistics Explained, Eurostat Stat. Explain. (2020). https://ec.europa.eu/eurostat/statisticsexplained/index.php?title=Electricity_price_statistics\#cite_note-1.

[3] European Parliament, EPBD recast, Directive 2010/31/EU of the European Parliament and of the Council of 19 May 2010 on the energy performance of 
buildings, 2010. Official Journal of the European Union.

[4] D. D’Agostino, L. Mazzarella, What is a Nearly zero energy building? Overview, implementation and comparison of definitions, J. Build. Eng. (2019).

https://doi.org/10.1016/j.jobe.2018.10.019.

[5] U. Berardi, ZEB and NZEB (Definitions, design methodologies, good practices, and case studies), in: Handb. Energy Effic. Build. A Life Cycle Approach, 2018. https://doi.org/10.1016/B978-0-12-812817-6.00038-3.

[6] G.P. Ramón Pascual, ZEBRA 2020: Nearly Zero-Energy Building Strategy 2020. Nearly Zero-Energy Building (nZEB) technology solutions, cost assessment and performance, 2016. http://www.zebra-monitoring.enerdata.eu/overall-buildingactivities/nzeb-definitions-by-country.html.

[7] D. D'Agostino, Assessment of the progress towards the establishment of definitions of Nearly Zero Energy Buildings (nZEBs) in European Member States, J. Build. Eng. 1 (2015) 20-32. https://doi.org/10.1016/j.jobe.2015.01.002.

[8] European Parliament, European Council, Directive (EU) 2018/844 on the energy performance of buildings and Directive 2012/27/EU on energy efficiency, Off. J. Eur. Union. (2018).

[9] Istat, Data warehouse del censimento della popolazione e delle abitazioni italiane, Annu. Stat. Ital. (2018).

[10] D.M. 26/06/2015, Adeguamento linee guida nazionali per la certificazione energetica degli edifici, Italy, 2015.

[11] F. Ascione, M. Borrelli, R.F. De Masi, F. De Rossi, G.P. Vanoli, Energy refurbishment of a University building in cold Italian backcountry. Part 2: Sensitivity studies and optimization, in: Energy Procedia, Elsevier Ltd, 2019: pp. 2-9. https://doi.org/10.1016/j.egypro.2018.12.010.

[12] D. Testi, M. Rocca, E. Menchetti, S. Comelato, Criticalities in the NZEB retrofit of scholastic buildings: Analysis of a secondary school in Centre Italy, in: Energy Procedia, Elsevier Ltd, 2017: pp. 252-264. https://doi.org/10.1016/j.egypro.2017.11.140.

[13] I. Ballarini, V. Corrado, F. Madonna, S. Paduos, F. Ravasio, Energy refurbishment of the Italian residential building stock: energy and cost analysis through the application of the building typology, Energy Policy. 105 (2017) 148-160. https://doi.org/10.1016/j.enpol.2017.02.026.

[14] F. Ruggiero, S. Di Turi, A. Mastrorilli, Study of an integrated retrofit system for energy positive buildings in urban areas, Adv. Model. Anal. A. 55 (2018) 136-143. https://doi.org/10.18280/ama_a.550306.

[15] M. Dubois, K. Allacker, Energy savings from housing: Ineffective renovation subsidies vs efficient demolition and reconstruction incentives, Energy Policy. 86 (2015) 697-704. https://doi.org/10.1016/j.enpol.2015.07.029.

[16] R. Mutschler, M. Rüdisüli, P. Heer, S. Eggimann, Benchmarking cooling and heating energy demands considering climate change, population growth and cooling device uptake, Appl. Energy. 288 (2021) 116636. https://doi.org/10.1016/j.apenergy.2021.116636.

[17] V. Pérez-Andreu, C. Aparicio-Fernández, A. Martínez-Ibernón, J.L. Vivancos, Impact of climate change on heating and cooling energy demand in a residential building in a Mediterranean climate, Energy. 165 (2018) 63-74. https://doi.org/10.1016/j.energy.2018.09.015.

[18] U. Berardi, P. Jafarpur, Assessing the impact of climate change on building heating and cooling energy demand in Canada, Renew. Sustain. Energy Rev. (2020). https://doi.org/10.1016/j.rser.2019.109681.

[19] E. Solgi, Z. Hamedani, R. Fernando, H. Skates, N.E. Orji, A literature review of 
night ventilation strategies in buildings, Energy Build. 173 (2018) 337-352. https://doi.org/10.1016/j.enbuild.2018.05.052.

[20] L. Ledo Gomis, M. Fiorentini, D. Daly, Potential and practical management of hybrid ventilation in buildings, Energy Build. 231 (2021) 110597. https://doi.org/10.1016/j.enbuild.2020.110597.

[21] D. D'Agostino, A. Greco, C. Masselli, F. Minichiello, The employment of an earthto-air heat exchanger as pre-treating unit of an air conditioning system for energy saving: A comparison among different worldwide climatic zones, Energy Build. 229 (2020) 110517. https://doi.org/10.1016/j.enbuild.2020.110517.

[22] R. Stasi, S. Liuzzi, S. Paterno, F. Ruggiero, P. Stefanizzi, A. Stragapede, Combining bioclimatic strategies with efficient HVAC plants to reach nearly-zero energy building goals in Mediterranean climate, Sustain. Cities Soc. 63 (2020). https://doi.org/10.1016/j.scs.2020.102479.

[23] J.M. Rey-Hernández, J.F. San José-Alonso, E. Velasco-Gómez, C. Yousif, F.J. Rey-Martínez, Performance analysis of a hybrid ventilation system in a near zero energy building, Build. Environ. 185 (2020) 107265.

https://doi.org/10.1016/j.buildenv.2020.107265.

[24] EN Standard 16798-1, Indoor Environmental Input Parameters for Design and Assessment of Energy Performance of Buildings Addressing Indoor Air Quality, Thermal Environment, Lighting and Acoustics-Module M1-6 CTI - Comitato Termotecnico Italiano, Milano Italy, (2019).

[25] UNI 10339:1995, Impianti aeraulici al fini di benessere. Generalità, classificazione e requisiti. Regole per la richiesta d'offerta, l'offerta, l'ordine e la fornitura., (1995).

[26] DesignBuilder Software Ltd, (2016). https://designbuilder.co.uk//software.

[27] the S.O. of the E.U. Eurostat, Electricity price statistics, 2020. https://ec.europa.eu/eurostat/statistics-explained/index.php?title=Electricity_price_ statistics\#cite_note-1. 